\title{
Using eggshell membranes as a DNA source for population genetic research
}

\author{
Krijn Baptist Trimbos · Joyce Broekman • \\ Rosemarie Kentie - Cees J. M. Musters · \\ Geert R. de Snoo
}

Received: 2 May 2009/Accepted: 13 May 2009/Published online: 4 July 2009

(C) The Author(s) 2009. This article is published with open access at Springerlink.com

\begin{abstract}
In the context of population genetic research, a faster and less invasive method of DNA sampling would allow large-scale assessments of genetic diversity and genetic differentiation with the help of volunteer observers. The aim of this study was to investigate the usefulness of eggshell membranes as a DNA source for population genetic research, by addressing eggshell membrane DNA quality, degeneration and cross-contamination. To this end, a comparison was made with blood-derived DNA samples. We have demonstrated $100 \%$ successful DNA extraction from post-hatched Black-tailed Godwit (Limosa limosa) eggshell membranes as well as from blood samples. Using 11 microsatellite loci, DNA amplification success was 99.1\% for eggshell membranes and $97.7 \%$ for blood samples. Genetic information within eggshell membrane DNA in comparison to blood DNA was not affected ( $F_{\mathrm{ST}}=$ $-0.01735, P=0.999)$ by degeneration or possible crosscontamination. Furthermore, neither degeneration nor cross-contamination was apparent in total genotypic comparison of eggshell membrane DNA and blood sample DNA. Our research clearly illustrates that eggshell membranes can be used for population genetic research.
\end{abstract}

Communicated by M. Wink.

K. B. Trimbos $(\bowtie) \cdot$ J. Broekman · C. J. M. Musters

G. R. de Snoo

Institute of Environmental Sciences (CML), Leiden University,

POB 9518, 2300 RA Leiden, The Netherlands

e-mail: trimbos@cml.leidenuniv.nl

R. Kentie

Animal Ecology Group (CEES), University of Groningen,

POB 14, 9750 AA Haren, The Netherlands
Keywords Limosa limosa Population genetics . Microsatellite $\cdot$ Eggshell membrane $\cdot$ DNA quality

\section{Introduction}

The most widely used material to investigate genetic population structure in birds are blood samples (Coulon et al. 2008; Hoglund et al. 2009; Larsson et al. 2008; Manier and Arnold 2005; Milot et al. 2008; Ortego et al. 2008; Ottvall et al. 2005). Obtaining blood samples is somewhat invasive, and in many countries only certified observers are allowed to sample blood. This pre-empts the possibility to build DNA collections over large spatial scales with the help of volunteers. In precocial species where the chicks leave the nesting area as soon as they can walk, eggshell remains can usually be collected after hatch. Egg-shells might be contaminated with parental and sibling DNA (Schmaltz et al. 2006; Strausberger and Ashley 2001; Taberlet and Fumagalli 1996; Taberlet and Waits 1998). However, if eggshells would still yield high quality DNA, the collection of eggshells would ease the collection of material for genetic population structure.

For the purpose of maternity and sex determination analyses, several studies have successfully isolated DNA from eggshell membranes (Bush et al. 2005; Pearce et al. 1997; Strausberger and Ashley 2001). These studies used eggshell membranes or swabs of eggshells as a DNA source, thereby examining 1-4 microsatellite loci only (Bush et al. 2005; Pearce et al. 1997; Strausberger and Ashley 2001). To date, however, eggshell membranes have never been used in population genetic research studies. Moreover, for this purpose, the general consensus among scientists is that a greater number of microsatellite loci need to be used (Kalinowski 2002, 2005; Pearce et al. 1997). 
To our knowledge, this is the first time that the usefulness of eggshell membranes for population genetic research has been thoroughly investigated using 11 microsatellite loci. In this study, we used DNA extracted from eggshell membranes of Black-tailed Godwits (Limosa limosa), employing blood sample DNA from Black-tailed Godwit individuals from the same nests as a control.

To investigate the usefulness of eggshell membranes as a DNA source in population genetic research, the following questions needed to be addressed. How often can DNA be successfully extracted from post-hatched Black-tailed Godwit eggshell membranes, and how does extraction frequency and quality compare with extraction of DNA from blood? Can eggshell membrane DNA be successfully amplified by PCR using 11 microsatellites, and how does this compare with amplification success in blood samples? Is the genetic information from eggshell membrane DNA samples the same as that from blood DNA samples? Is cross-contamination or DNA degeneration more prominent in eggshell membrane-derived DNA than in blood-derived DNA?

\section{Methods}

Study site and genetic sampling

Black-tailed Godwit egg-shell membranes and blood samples from hatched chicks were collected in southwest Fryslân, northern Netherlands (see Schroeder et al. 2008; van den Brink et al. 2008 for description of study area). Early during incubation, nests were located and visited. To determine hatching date, the developmental stage of the eggs was determined by the floating method (Liebezeit et al. 2007). Around the hatching date, the nests were visited once per day to obtain as many eggshell and blood samples per nest as possible. Blood was stored in $97 \%$ alcohol buffer and eggshells in individual plastic bags to minimise post-sampling contamination. Both were stored at $-70^{\circ} \mathrm{C}$ for later extraction.

Eggshell membrane and blood sample comparison

A stepwise approach was adopted. First, DNA was extracted from the total number of collected eggshells (47) and blood samples (48) from 18 different nests. Second, through PCR amplification of eggshell membrane samples with different purity values, using 4 microsatellites, the effect of purity on amplification was validated and visualised by loading the samples on a $1.2 \%$ agarose gel. Finally, after this validation, from the total number of 47 eggshells and 48 blood samples, 21 eggshell membrane and 20 blood DNA samples from the same 7 nests were selected for microsatellite PCR, based on DNA purity. Genetic differentiation between the selected 20 blood and 21 eggshell membrane DNA samples was calculated to check whether eggshell membrane DNA harboured the same genetic information as blood samples.

To confirm that complete molecular DNA could be obtained from post-hatched eggshell membranes, we matched genotypes between eggshell membrane and blood sample DNA from chicks from the same nests. In this way, we also checked for possible cross-contamination of eggshell membrane DNA with DNA from another chick or adult in the same nest or from exogenous DNA. If an eggshell membrane DNA sample had the same genotype over 11 microsatellite loci compared to a given blood sample, this was called a match. Possible matches between blood samples and eggshells were unknown beforehand. However, the chance of a possible match per nest was maximised by using only the nests with as many blood and eggshell membrane samples as possible.

\section{DNA extraction}

DNA was extracted from 6-10 $\mu$ l of blood using the ammonium acetate method as described by Richardson et al. (2001). The Qiagen Dneasy Tissue Kit (Qiagen 2003) was used to extract DNA from eggshell membranes, with minor modifications as described by Bush et al. (2005). Subsequently, we modified this protocol by adding $100 \mu \mathrm{l}$ Buffer AE instead of $200 \mu$ in step 9 of the Qiagen Animal Tissue Protocol Modification. The incubation step that followed was extended from 5 to $10 \mathrm{~min}$. Additionally, after spinning down the column, the supernatant was used a second time on the column to maximise DNA yield. Eggshell membrane-derived DNA samples were used undiluted. DNA quality and quantity were checked twice, using the NanoDrop ND-1000 (Thermo Scientific) for 260/ 280 ratios and concentration values. Additionally, DNA degeneration in all samples was visualised by running them through a $1.2 \%$ agarose gel undiluted and checking for smears. For sizing and quantification approximation of amplification fragments, a GeneRuler $1 \mathrm{~kb}$ (Fermentas Life Science) was used. For optimal PCR amplification, blood samples were diluted to concentrations below $20 \mathrm{ng} / \mu \mathrm{l}$. Eggshell membrane DNA samples were used undiluted straight from the Qiagen DNeasy Tissue Kit extraction, as this had already resulted in successful PCR amplification.

\section{Microsatellite genotyping}

We used 11 microsatellite loci (LIM3, LIM5, LIM8, LIM10, LIM11, LIM12a, LIM24, LIM25, LIM26, LIM30, and LIM33) constructed especially for the Black-tailed Godwit as described by Verkuil et al. (2009). The final volumes of the 
PCR amplification mix were $11 \mu \mathrm{l}$ and included $1-5 \mathrm{ng}$ DNA for blood samples or 1-30 ng DNA for eggshell membrane samples, $1.65 \mathrm{mM} \mathrm{MgCl}_{2}, 2.5 \mu \mathrm{M}$ dNTPs, $0.5 \mu \mathrm{M}$ forward primer with $\mathrm{M} 13$ extension, $0.5 \mu \mathrm{M}$ reverse primer, $1 \mu \mathrm{M}$ fluorescent-labelled M13 primer with the same universal extension as the forward primer, $10 \times$ PCR buffer and $0.45 \mathrm{U}$ Taq DNA Qiagen polymerase.

The polymerase chain reaction program used was as described by Verkuil et al. (2009), but with one minor modification: the final PCR step was extended from 5 to $20 \mathrm{~min}$. The resulting PCR products were analysed using a MegaBace 1000 series (Amersham Biosciences) and allele sizes were assigned using a Fragment Profiler 1.2 (Amersham Biosciences). For each sample, PCR amplification success was noted as the successful percentage of positive genotypes scored over 11 microsatellites. To minimise contamination with exogenous DNA during PCR, pre- and post-PCR pipetting were carried out in different rooms. Additionally, to address these potential contamination problems, tubes without DNA samples were included in every PCR reaction as a negative control.

\section{Statistical analysis}

Possible differences in genetic information between the two sample sets were addressed by calculating pairwise $F_{\text {ST }}$ estimates over 15,000 permutations and a significance level of 0.05 in Arlequin 3.0 (Excoffier and Schneider 2005). To investigate possible allelic dropout and null allele problems in the eggshell membrane DNA sample set due to possible DNA degeneration, we used MicroChecker 2.2.3 (van Oosterhout et al. 2004) with a 95\% confidence interval over 10,000 runs.

To match genotypes between eggshell membrane DNA and blood samples from the same nest, we calculated the minimum and maximum number of successful matches that could be expected in each single nest, assuming no contamination or degeneration problems. These values were obtained from the number of eggshell membranes and blood samples within one nest and were then compared with the original number of eggs present within that nest. For instance, if three eggshells and four blood samples were collected from one nest originally with four eggs, this resulted in both a minimum and a maximum of three expected matches. The observed number of matches per nest was then validated by comparing it with the minimum number of expected matches per nest.

\section{Results}

DNA was successfully extracted from all 47 eggshell membranes, with DNA concentrations averaging $248 \mathrm{ng} / \mu \mathrm{l}$

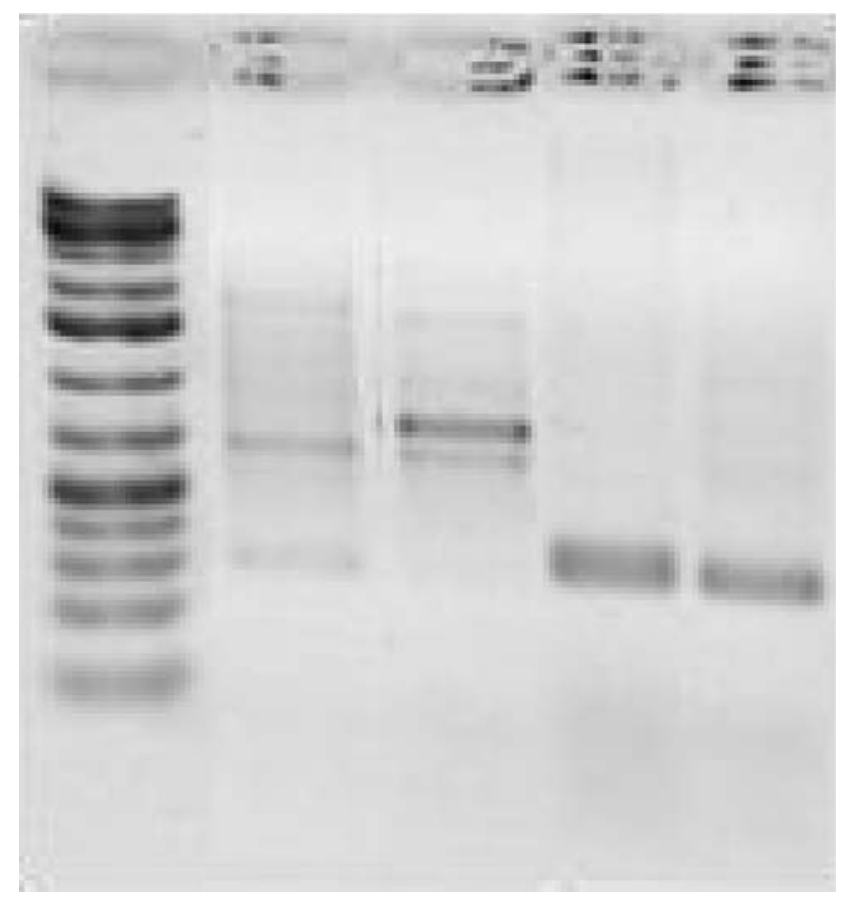

Fig. 1 Amplification bands of 4 eggshell membrane DNA samples with different purity values using 1 microsatellite locus. The first lane shows the GeneRuler $1 \mathrm{~kb}$, the second and third lanes samples with respective purity values of 1.5 and 1.35 , and the fourth and fifth lanes samples with respective purity values of 2.06 and 2.1

(range 32.7-543.68 $\mathrm{ng} / \mu \mathrm{l}$ ). This demonstrates that all sample concentrations were adequate for PCR purposes. A $260 / 280$ ratio, also termed purity value, of $\sim 1.8$ or higher is generally accepted as pure DNA. Our nanodrop spectrophotometer measurements demonstrated pure DNA in $72 \%$ of the samples tested according to the 260/280 ratio. DNA purity ranged from 0.44 to 2.11 , with a total average of 1.77 .

As can be seen in Fig. 1, DNA samples with purity values of 1.5 or lower showed aspecific amplification with several different bands within a lane, while samples with purity values over 2.0 showed single and clear amplification bands. A purity value of 1.6 or higher was regarded as DNA of high purity, which we used for our microsatellite PCR. Some (5) eggshell membrane samples with a DNA purity below 1.6 were extracted a second time. After this second extraction, 3 out of these 5 eggshell membrane samples gave a DNA purity of $>1.6$. As a consequence, the percentage of samples with pure DNA rose to $79 \%$ and the mean DNA purity value to 1.83 . Blood sample DNA extractions were also successful for all 48 samples. The DNA concentrations found averaged $317 \mathrm{ng} / \mu \mathrm{l}$ (range 33.77-1,051.36 ng/ $\mu \mathrm{l})$. Our nanodrop spectrophotometer measurements demonstrated DNA of high purity in $100 \%$ of the samples tested according to the 260/280 ratio. DNA purity ranged from 1.86 to 1.99 , with a total average of 
Table 1 Black-tailed Godwit (Limosa limosa) eggshell membrane and blood DNA samples with their concentrations and purity, PCR amplification success (PCRamp), minimum expected matches (Exp Min Matches), maximum expected matches (Exp Max Matches) and observed matches per nest

\begin{tabular}{|c|c|c|c|c|c|c|c|c|c|}
\hline $\begin{array}{l}\text { Eggshell membrane } \\
\text { sample }\end{array}$ & Purity & $\begin{array}{l}\text { PCRamp } \\
(\%)\end{array}$ & $\begin{array}{l}\text { Blood } \\
\text { sample }\end{array}$ & Purity & $\begin{array}{l}\text { PCRamp } \\
(\%)\end{array}$ & $\begin{array}{l}\text { Eggs present within } \\
\text { the nest }\end{array}$ & $\begin{array}{l}\text { Exp Min } \\
\text { Matches }\end{array}$ & $\begin{array}{l}\text { Exp Max } \\
\text { Matches }\end{array}$ & $\begin{array}{l}\text { Observed } \\
\text { matches }\end{array}$ \\
\hline 1.1 & 2.06 & 100 & 1.1 & 1.94 & 82 & 4 & 1 & 2 & 1 \\
\hline 1.2 & 2.02 & 100 & 1.2 & 1.97 & 100 & & & & \\
\hline 1.3 & 2.03 & 100 & & & & & & & \\
\hline 2.1 & 2.11 & 100 & 2.1 & 1.92 & 100 & 5 & 0 & 2 & 0 \\
\hline \multirow[t]{2}{*}{2.2} & 1.97 & 100 & 2.2 & 1.95 & 82 & & & & \\
\hline & & & 2.3 & 1.94 & 100 & & & & \\
\hline 3.1 & 2.01 & 100 & 3.1 & 1.95 & 100 & 4 & 3 & 3 & 3 \\
\hline 3.2 & 2.06 & 100 & 3.2 & 1.94 & 100 & & & & \\
\hline 3.3 & 2.09 & 100 & 3.3 & 1.93 & 100 & & & & \\
\hline 3.4 & 2.06 & 100 & & & & & & & \\
\hline 4.1 & 2.08 & 100 & 4.1 & 1.90 & 100 & 4 & 2 & 2 & 2 \\
\hline \multirow[t]{3}{*}{4.2} & 2.1 & 100 & 4.2 & 1.94 & 100 & & & & \\
\hline & & & 4.3 & 1.97 & 91 & & & & \\
\hline & & & 4.4 & 1.95 & 100 & & & & \\
\hline 5.1 & 1.76 & 100 & 5.1 & 1.95 & 100 & 4 & 3 & 3 & 3 \\
\hline 5.2 & 1.67 & 100 & 5.2 & 1.93 & 100 & & & & \\
\hline 5.3 & 1.84 & 82 & 5.3 & 1.94 & 100 & & & & \\
\hline 5.4 & 1.93 & 100 & & & & & & & \\
\hline 6.1 & 1.96 & 100 & 6.1 & 1.98 & 100 & 4 & 2 & 3 & 2 \\
\hline 6.2 & 1.95 & 100 & 6.2 & 1.96 & 100 & & & & \\
\hline 6.3 & 2.09 & 100 & 6.3 & 1.89 & 100 & & & & \\
\hline 7.1 & 1.94 & 100 & 7.1 & 1.97 & 100 & 4 & 1 & 2 & 2 \\
\hline 7.2 & 1.99 & 100 & 7.2 & 1.95 & 100 & & & & \\
\hline 7.3 & 2.11 & 100 & & & & & & & \\
\hline
\end{tabular}

1.94. We selected 21 eggshell membrane and 20 blood DNA samples of high purity (Table 1) from the same seven nests.

One eggshell membrane DNA isolate out of 21 and 3 blood isolates out of 20 did not amplify for 2 and 5 of the 11 microsatellite loci. The remaining 20 eggshell membrane and 17 blood samples amplified for all 11 loci. Theoretically, amplification failure could have occurred in 21 samples $\times 11$ microsatellite loci for the eggshell membrane set and 20 samples $\times 11$ microsatellite loci for the blood sample set. This resulted in successful amplification rates of $99.1 \%$ in the total eggshell membrane group and $97.7 \%$ in the total blood sample group (Table 1).

Degeneration of eggshell membrane DNA was slight to non-existent and there was no apparent DNA degeneration in the blood samples, as can be seen in Fig. 2. DNA degeneration could be observed as smears emanating from the bands at the top of the gel, which represent complete molecular DNA. As can be seen in all samples where DNA degeneration occurred, a clear band representing complete molecular DNA could be observed, demonstrating that

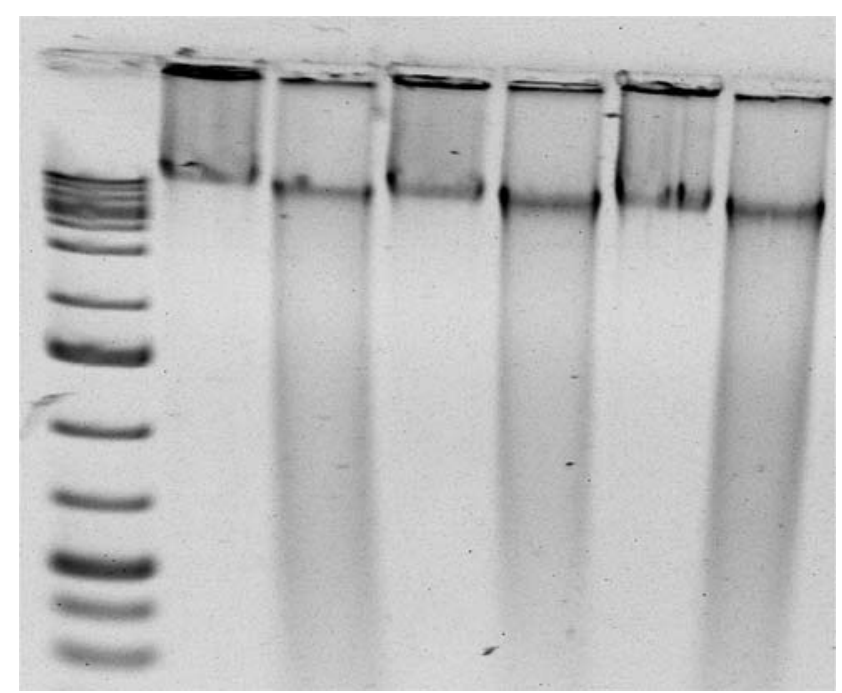

Fig. 2 Gel visualizing DNA degeneration of different blood and eggshell membrane samples. The first lane shows the GeneRuler $1 \mathrm{~kb}$, the second lane a blood sample and the third lane an eggshell membrane sample. Subsequent blood and eggshell membrane samples were loaded on the gel in the same order (lanes 4-7) 
DNA present in the samples was still of high quality. As expected, blood samples showed no apparent DNA degeneration. This pattern was observed in all the eggshell membrane and blood DNA samples.

An $F_{\text {ST }}$ value of only -0.01735 was found between the 21 eggshell membrane and 20 blood DNA samples, demonstrating that as a group the eggshell membrane samples were no different $(P=0.999)$ from the blood samples in terms of the genetic information they contained. Analyses with Micro-checker demonstrated no presence of null alleles or allelic dropout within the eggshell membrane DNA dataset.

The genotypes of the 21 eggshell membrane and 20 blood samples were compared in all 7 nests independently. Table 1 shows the relative PCR amplification success per sample and the minimum expected, maximum expected and observed number of matches. All in all, 12 genotype matches over all 11 microsatellites were observed. In other words, direct linkage of eggshell membrane DNA to a DNA blood sample belonging to a chick was demonstrated in 12 cases. The number of observed genotype matches, over all 11 microsatellites, was never lower than the minimum expected number of matches. This held for all the nests.

\section{Discussion}

We have demonstrated successful DNA isolation from $100 \%$ of the eggshell membranes used. These results compare favourably with those of Bush et al. (2005), who achieved a $96 \%$ success rate in extraction from eggshell membranes. It may be that the eggshell membranes used in the present study were fresher than those used by Bush et al. (2005), leading to fewer extraction failures and higher DNA concentrations. DNA of high purity ( $>1.6)$ with good concentrations for PCR was isolated from $79 \%$ of the eggshell membranes and $100 \%$ of the blood samples. Bush et al. (2005) stored eggshells at room temperature rather than freezing them. This will result in the veined inner membranes drying and separating from the outer eggshell making them much easier to collect for DNA isolation. Additionally, the $79 \%$ could also be increased by taking more eggshells out of one nest.The method of sampling $100 \%$ of all 17 nests used in this study resulted in at least one DNA isolate generated from eggshell membranes with a DNA purity value of $>1$.6. In this way the $79 \%$ extraction percentage from eggshell membranes suitable for microsatellite PCR should not pose problems for population genetic research.

We demonstrated PCR amplification success in $99.1 \%$ of the eggshell membrane samples, with only 1 eggshell membrane isolate out of 21 not amplifying for two microsatellite loci. As amplification success was lower in the total blood sample set $(97.7 \%)$, this amplification failure of respectively 0.9 and $2.3 \%$ was seen as a chance PCR event. This shows that eggshell membrane DNA isolates did not yield DNA with more amplification problems than blood DNA isolates. Additionally, failed amplification was not correlated with the purity values of these samples (Table 1).

When comparing DNA sample sets from different populations of varying DNA quality for the purpose of population genetic research, DNA degeneration and cross-contamination may cause genetic diversity and thus genetic structure values $\left(F_{\mathrm{ST}}\right)$ to be affected. As became clear from Fig. 2, DNA from eggshell membranes exhibited a certain amount of DNA degeneration. As such, we wished to establish whether the DNA from 21 eggshell membranes harboured the same genetic information over 11 microsatellite loci as that from 20 blood samples from the same 7 nests. The genetic differentiation between the two groups was extremely minor and highly non-significant, showing that the two DNA sets were genetically the same. This indicates that even if the eggshell membrane group was affected by degeneration or cross-contamination, this had no influence on genetic differentiation $\left(F_{\mathrm{ST}}\right)$. Additionally, as most studies use 10 or more microsatellite loci to calculate genetic differentiation and diversity values (Coulon et al. 2008; Larsson et al. 2008; Ortego et al. 2008; Manier and Arnold 2005), these results make clear that eggshell membrane DNA can be effectively used to calculate these values for the purpose of population genetic research.

However, while genetic diversity and $F_{\mathrm{ST}}$ values were clearly unaffected by degeneration and possible crosscontamination prominence, we were keen to assess these issues more precisely within eggshell membrane DNA. This was done by comparing the genotypes from eggshell membrane and blood samples taken from individuals from the same 7 nests over 11 microsatellite loci. Within these nests, a total of 12 matching genotypes over 11 microsatellite loci were found. The observed number of matches was never lower than the minimum expected number of matches per nest. Additionally, no allelic dropout or null allele problems were observed. This illustrates that DNA degeneration and cross-contamination were not a serious issue.

Summarising, eggshell membranes taken from eggshells are a very good alternative to blood samples for the purpose of population genetic research. In this context, the minor differences in DNA quality between eggshell membrane DNA and blood DNA are insignificant. Our results show, for the first time, that eggshell membranes can be very useful as a DNA source for this type of research. 
Acknowledgments We hereby declare that the experiments comply with the current laws of the country in which they were performed. We would like to thank Theunis Piersma, Jos Hooijmeijer, Petra de Goeij, Pedro Lourenco and the rest of the Groningen University Black-tailed Godwit group for their help in collecting eggshells and blood samples, storing the eggshells and providing laboratory space for DNA extractions. Marco van der Velde from the University of Groningen was of great help with these extractions. Yvonne Verkuil from the Groningen University helped with understanding the Arlequin and Micro-checker software. Klaas Vrieling and Rene Glas of the Leiden Institute of Biology (IBL) were helpful with PCR amplifications and providing laboratory space. We are also grateful to Nigel Harle for brushing up our English.

Open Access This article is distributed under the terms of the Creative Commons Attribution Noncommercial License which permits any noncommercial use, distribution, and reproduction in any medium, provided the original author(s) and source are credited.

\section{References}

Bowkett AE, Plowman AB, Stevens JR, Davenport TRB, van Vuuren BJ (2009) Genetic testing of dung identification for antelope surveys in the Udzungwa Mountains, Tanzania. Conserv Genet 10:251-255. doi:10.1007/s10592-008-9564-7

Bush KL, Vinsky MD, Aldridge CL, Paszkowski CA (2005) A comparison of sample types varying in invasiveness for use in DNA sex determination in an endangered population of greater Sage-Grouse (Centrocercus uropihasianus). Conserv Genet 6:867-870. doi:10.1007/s10592-005-9040-6

Coulon A, Fitzpatrick JW, Bowman R, Stith BM, Makarewich CA, Stenzler LM, Lovette IJ (2008) Congruent population structure inferred from dispersal behaviour and intensive genetic surveys of the threatened Florida scrub-jay (Aphelocoma coerulescens). Mol Ecol 17:1685-1701. doi:10.1111/j.1365-294X.2008.03705.x

Excoffier LGL, Schneider S (2005) Arlequin ver. 3.0: an integrated software package for population genetics data analysis. Evol Bioinform Online 1:47-50

Hoglund J, Johansson T, Beintema A, Schekkerman H (2009) Phylogeography of the black-tailed Godwit Limosa limosa: substructuring revealed by mtDNA control region sequences. J Ornithol 150:45-53. doi:10.1007/s10336-008-0316-8

Kalinowski ST (2002) How many alleles per locus should be used to estimate genetic distances? Heredity 88:62-65. doi:10.1038/sj. hdy.6800009

Kalinowski ST (2005) Do polymorphic loci require large sample sizes to estimate genetic distances? Heredity 94:33-36. doi:10.1038/ sj.hdy. 6800548

Larsson JK, Jansman HAH, Segelbacher G, Hoglund J, Koelewijn HP (2008) Genetic impoverishment of the last black grouse (Tetrao tetrix) population in the Netherlands: detectable only with a reference from the past. Mol Ecol 17:1897-1904. doi:10.1111/ j.1365-294X.2008.03717.x

Liebezeit JR, Smith PA, Lanctot RB, Schekkerman H, Tulp I, Kendall SJ, Tracy DM, Rodriques RJ, Meltofte H, Robinson JA, Gratto-
Trevor C, McCaffery BJ, Morse J, Zack SW (2007) Assessing the development of shorebird eggs using the flotation method: speciesspecific and generalized regression models. Condor 109:32-47. doi:10.1650/0010-5422(2007)109[32:ATDOSE]2.0.CO;2

Manier MK, Arnold SJ (2005) Population genetic analysis identifies source-sink dynamics for two sympatric garter snake species (Thamnophis elegans and Thamnophis sirtalis). Mol Ecol 14:3965-3976. doi:10.1111/j.1365-294X.2005.02734.x

Milot E, Weimerskirch H, Bernatchez L (2008) The seabird paradox: dispersal, genetic structure and population dynamics in a highly mobile, but philopatric albatross species. Mol Ecol 17:16581673. doi:10.1111/j.1365-294X.2008.03700.x

Ortego J, Calabuig G, Aparicio J, Cordero PJ (2008) Genetic consequences of natal dispersal in the colonial lesser kestrel. Mol Ecol 17:2051-2059. doi:10.1111/j.1365-294X.2008.03719.x

Ottvall R, Hoglund J, Bensch S, Larsson K (2005) Population differentiation in the redshank (Tringa totanus) as revealed by mitochondria DNA and amplified fragment length polymorphism markers. Conserv Genet 6:321-331. doi:10.1007/s10592-0054973-3

Pearce JM, Fields RL, Scribner KT (1997) Nest materials as a source of genetic data for avian ecological studies. J Field Ornithol $68: 471-481$

Qiagen (2003) DNeaasy Tissue Handbook. protocol for isolation of total DNA from animal tussues. QIAGEN. Vlaencia, California, USA, pp. $18-20$

Richardson DS, Jury FL, Blaakmeer K, Komdeur J, Burke T (2001) Parentage assignment and extra-group paternity in a cooperative breeder: the Seychelles warbler (Acrocephalus sechellensis) Mol Ecol 10:2263-2273

Schmaltz G, Somers CM, Sharma P, Quinn JS (2006) Non-destructive sampling of maternal DNA from the external shell of bird eggs. Conserv Genet 7:543-549. doi:10.1007/s10592-005-9065-x

Schroeder J, Lourenco PM, Van der Velde M, Hooijmeijer JCEW, Both C, Piersma T (2008) Sexual dimorphism in plumage and size in black-tailed Godwits Limosa limosa limosa. Ardea 96:2537

Strausberger BM, Ashley MV (2001) Eggs yield nuclear DNA from egg-laying female cowbirds, their embryos and offspring. Conserv Genet 2:385-390. doi:10.1023/A:1012526315617

Taberlet P, Fumagalli L (1996) Owl pellets as a source of DNA for genetic studies of small mammals. Mol Ecol 5:301-305. doi: 10.1111/j.1365-294X.1996.tb00318.x

Taberlet P, Waits LP (1998) Non-invasive genetic sampling. Trends Ecol Evol 13:26-27. doi:10.1016/S0169-5347(97)01276-7

Van den Brink V, Schroeder J, Both C, Lourenco PM, Hooijmeijer JCEW, Piersma T (2008) Space use by Black-tailed Godwits Limosa limosa limosa during settlement at a previous or a new nest location. Bird Study 55:188-193

Van Oosterhout C, Hutchinson WF, Wills DPM, Shipley P (2004) MICRO-CHECKER: software for identifying and correcting genotyping errors in microsatellite data. Mol Ecol Notes 4:535538. doi:10.1111/j.1471-8286.2004.00684.x

Verkuil YI, Trimbos K, Haddrath O, Baker AJ (2009) Characterization of polymorphic microsatellite DNA markers in the blacktailed godwit (Limosa limosa: Aves). Mol Ecol (in press) 